\title{
Is there a rationale to contact the unemployed right from the start? Evidence from a natural field experiment
}

Citation for published version (APA):

van Landeghem, B., Cörvers, F., \& de Grip, A. (2016). Is there a rationale to contact the unemployed right from the start? Evidence from a natural field experiment. ROA. ROA Research Memoranda No. 011 https://doi.org/10.26481/umaror.2016011

Document status and date:

Published: 01/01/2016

DOI:

10.26481/umaror.2016011

Document Version:

Publisher's PDF, also known as Version of record

Please check the document version of this publication:

- A submitted manuscript is the version of the article upon submission and before peer-review. There can be important differences between the submitted version and the official published version of record.

People interested in the research are advised to contact the author for the final version of the publication, or visit the DOI to the publisher's website.

- The final author version and the galley proof are versions of the publication after peer review.

- The final published version features the final layout of the paper including the volume, issue and page numbers.

Link to publication

\footnotetext{
General rights rights.

- You may freely distribute the URL identifying the publication in the public portal. please follow below link for the End User Agreement:

www.umlib.nl/taverne-license

Take down policy

If you believe that this document breaches copyright please contact us at:

repository@maastrichtuniversity.nl

providing details and we will investigate your claim.
}

Copyright and moral rights for the publications made accessible in the public portal are retained by the authors and/or other copyright owners and it is a condition of accessing publications that users recognise and abide by the legal requirements associated with these

- Users may download and print one copy of any publication from the public portal for the purpose of private study or research.

- You may not further distribute the material or use it for any profit-making activity or commercial gain

If the publication is distributed under the terms of Article $25 \mathrm{fa}$ of the Dutch Copyright Act, indicated by the "Taverne" license above, 


\section{Is there a rationale to contact the unemployed right from the start? \\ Evidence from a natural field experiment}

Bert van Landeghem, Frank Cörvers, Andries de Grip

\section{ROA Research Memorandum}

ROA-RM-2016/11

Researchcentrum voor Onderwijs en Arbeidsmarkt | ROA Research Centre for Education and the Labour Market | ROA 


\title{
Is there a rationale to contact the unemployed right from the start? Evidence from a natural field experiment
}

\author{
Bert van Landeghem \\ Frank Cörvers \\ Andries de Grip
}

ROA-RM-2016/11*

November 2016

Research Centre for Education and the Labour Market

Maastricht University

P.O. Box 616, 6200 MD Maastricht, The Netherlands

$\mathrm{T}+31433883647 \mathrm{~F}+31433884914$

secretary-roa-sbe@maastrichtuniversity.nl

www.roa.nl

\footnotetext{
* The ROA Research Memorandum Series was created in order to make research results available for discussion, before those results are submitted for publication in journals.
} 


\section{Abstract \\ Is there a rationale to contact the unemployed right from the start? Evidence from a natural field experiment**}

Active Labour Market Policies (ALMPs) often exclusively target towards the longterm unemployed. Although it might be more efficient to intervene earlier in order to prevent long-term unemployment rather than to cure it, the climate of austerity in Eurozone countries is spreading a tendency to further reduce the basic counselling for those who become unemployed. This study investigates the impact on employment chances of a relatively light and inexpensive intervention. In a field experiment in a public employment office in Flanders, a random selection of clients were invited for a mandatory information session in the first month of the unemployment spell, while the control group were invited after four months of unemployment. Although the average intention-to-treat effect we find is not significant, the early intervention appears to be very beneficial for those with low education.

JEL classification: D04, D61, J64, J68

Keywords: active labour market policies, unemployment, natural field experiment

Bert van Landeghem

University of Sheffield

Department of Economics and InstEAD

Western Bank

Sheffield S10 2TN

United Kingdom

b.vanlandeghem@sheffield.ac.uk

and Maastricht University/ROA and IZA

Andries de Grip

Maastricht University

ROA

P.O. Box 616

NL-6200 MD Maastricht

The Netherlands

a.degrip@maastrichtuniversity.nl

and IZA
Frank Cörvers

Maastricht University

ROA

P.O. Box 616

NL-6200 MD Maastricht

The Netherlands

frank.corvers@maastrichtuniversity.nl and Tilburg University/ReflecT

\footnotetext{
** We are grateful for fruitful discussions at the 2015 WPEG conference, and seminars at Maastricht University and the University of Sheffield. In particular, we would like to thank Sarah Brown, Thomas Dohmen and Karl Taylor, who have provided us with very useful comments during the process of writing this paper. We also thank the editor as well as the two referees, who offered us constructive in-depth comments. Finally, we are greatly indebted to the staff of the FETO, both at the central level as well as at the level of the participating office, for their time and effort, for proactively providing us with advice and useful information, and for their logistic support. The Network Social Innovations (NSI) provided financial support.
} 


\section{Introduction}

The design of Active Labour Market Policies (ALMPs) is constantly being debated in academia, in the media, and at many policy levels. Despite the fact that public employment services, re-integration programmes and subsidies absorb a substantial amount of public spending, the impact of ALMPs is not unambiguously positive (Card et al., 2010). Indeed, the mechanisms through which these programmes can affect unemployed workers' behaviour are rather diverse. Well-known is that intensive training programmes and subsidized jobs might lead to a locking-in effect (Van Ours, 2004) in case of a high work load of the training programme and consequently little time for the participants to search for a new job. Mandatory training programmes might also have a threat effect, which is illustrated by a peak in the transition from unemployment to employment just before the date at which such programmes become mandatory (Graversen and Van Ours, 2011).

Many training or coaching programmes, especially the more expensive ones, are often only available for those who have been unemployed for an extensive period of time. For example, Van der Klaauw and Van Ours (2013) study employment bonuses that are available for individuals with an unemployment spell that exceeds one year. Blundell et al. (2004) meticulously evaluate the employment effects of the extensive New Deal programme for 18-24 year olds in the United Kingdom, which involves mandatory job search assistance and wage subsidies. However, these treatments only start six months 
after first receiving job seekers allowance. Moreover, in their search for further spending cuts, European governments try to replace their traditional employment services by digital self-service applications. In Flanders, since 2015 registration of the unemployed is being more centralized. While the unemployed had the option to come to a local office and to enrol face-to-face at the counter and have a chat for a few minutes with a caseworker, they are now being asked to enrol through the Internet or by telephone through the central service line.

While obviously the long-term unemployed are the most vulnerable group with the largest distance to the labour market, one might find good reasons to intervene earlier into the unemployment spell in order to prevent long-term unemployment rather than to cure it. Indeed, the well-documented scarring effects of long-term unemployment such as lower mental health (Knabe and Rätzel, 2011), and lower earning potential and reduced career opportunities (Hijzen et al., 2010; Oreopoulos et al., 2012) might imply that the late timing of such programmes dampens their efficiency. In addition, Kroft et al. (2013) conclude from a natural field experiment that, ceteris paribus, long-term unemployed applicants are less likely to receive a response from employers. Hence, it seems that governments are in search for the right balance in their ALMPs. On the one hand, one aims to preserve sufficient resources for intensive re-integration programmes of vulnerable groups such as the long-term unemployed. On the other hand, one needs to make sure that unemployed workers for whom the distance to the labour market is not yet too far receive appropriate guidance and monitoring in order to accelerate the transition to 
work, and, most importantly, to prevent the unemployed ending up in a vicious circle of long-term unemployment. A fairly recent literature in behavioural economics has indeed indicated that it is often possible to significantly steer human behaviour in various fields in a very inexpensive way (e.g. Fellner et al., 2013; Altmann and Traxler, 2014 and Crossley et al., 2014). In a labour market context, Altmann et al. (2015) investigate through a large-scale natural field experiment the effect of an information brochure, sent out four to eight weeks after becoming unemployed, on the job finding rate of German unemployed job seekers: the brochure offers information about the labour market conditions as well as on evidence-based facts such as the effectiveness and importance of devoting time to job search, the consequences of unemployment (e.g. reduced mental health), and different alternative job search strategies. They conclude that sending out such brochures has a small positive effect on the exit rate out of unemployment, at least for those who are at risk of becoming long-term unemployed. Given the inexpensive nature of the intervention, such a campaign can be seen as highly cost-effective. One might therefore wonder whether it is efficient to backload reintegration efforts to high-costs interventions for the long-term unemployed as trying to prevent long-term unemployment could be both much cheaper and more effective. This paper aims to contribute to our understanding of how rather cheap early interventions can improve the transition from unemployment to work.

In this way our paper also contributes to the academic literature in this field which mainly focuses at high-costs interventions for the long-term unemployed. In a field ex- 
periment in a public employment office in Flanders, a random selection of clients were invited for a mandatory information session in the first month of their unemployment spell, while the control group were invited for this session after four months of unemployment. The information session comprises of a 2.5-hours collective session followed by a five-minutes one-on-one interview with a caseworker. It is important to note that we will be measuring the intention-to-treat effect of the information session: some unemployed will find a job after being formally contacted but before having attended the information session, whereas others who got an invitation might not appear at the information session for different reasons.

On average, we find a positive though insignificant overall effect of being allocated to the treatment group on the job-finding rate. However, we have strong evidence that the treatment has had a major positive impact on the job-finding rate of the low-educated.

The remainder of the paper is structured as follows. Section two gives some background information on the case study, and outlines the randomized intervention. Section three documents the procedure for implementation of the randomized intervention, offers descriptive statistics as well as evidence of compliance. Section four details the hypotheses and the main empirical model, while Section five discusses the main results and extensions. Section six concludes. 


\section{The Randomized Intervention and Its Context}

During the period of the case study, the coaching, mentoring and training of the unemployed was a regional matter in the Federal State of Belgium. In Flanders, the regional employment agency is called the Flemish Employment and Vocational Training Office (FETO). ${ }^{1}$ Our partner for the case study is a local FETO office in a coastal area. The FETO has a well-established practice across all its offices to divide the unemployed in three main age categories, the category below 25 (youngsters), the category in the age range of 25 to 49 (middle-aged) and the category of 50 and above (older) (VDAB, 2015a). Each age group has its own coaching programme with its own approaches. The youngsters, on the one hand, are highly prioritized and are being coached very intensively in a mandatory programme. The older unemployed, on the other hand, have traditionally enjoyed a softer regime with less monitoring and surveillance. ${ }^{2}$ Implementing a randomized intervention for these two groups would imply ethical issues for the former (a randomized denial instead of a randomized access) and practical issues for the latter (such as small sample sizes).

For the above reasons, we have focussed on the middle group, aged 25 to 49 . At the time of the trial, a mandatory collective information session was the first active

\footnotetext{
${ }^{1}$ At that time, the National Employment Office (NEO), which also coordinates the financing of benefit payments, was responsible for judging the appropriateness of the job search efforts of the unemployed, and was allowed to impose benefit sanctions if job finding efforts were repeatedly found to be below the minimum threshold. This implied that the FETO, responsible for monitoring, would transmit the client's file to the NEO which could then decide about sanctions.

${ }^{2}$ However, from April 2009 onwards, a coaching programme for the older unemployed was introduced, with the maximum age for whom the programme is mandatory increasing from 52 in April 2009 up to 57 from 2012 onwards (VDAB, 2014).
} 
attempt of the public employment service (FETO) to get in touch with this age group of unemployed individuals. A formal invitation was sent out with a proposed date, time and place to attend a session. In case the invitees were unable to attend the information session because of an application interview or another legitimate reason, they were being asked to notify the agency the day before the information session at the latest. If not, they would be discarded from the FETOs unemployment registry. ${ }^{3}$ Generally, the FETO tried to invite around 30 individuals per information session, although the turn-up is generally significantly lower due to cancellations or illegitimate absences. The first 2 to 2.5 hours of an information session were dedicated to a collective part. The participants received an overview of the working of the employment office and the different services located in the building. Next, they were taught about certain rights (such as reimbursement of travel costs when going to an application interview), and about a range of ALMPs such as employers subsidies, training trajectories and training subsidies. The session then continued with a demonstration of the FETOs website, and participants were shown how they can create an online profile and CV, find job vacancies that match their preferences and skills, and how they can set up E-mail alerts. Finally, participants were invited to take place behind a computer and optimize their own online profile. After the collective part, there were short one-on-one meetings between each participant and a caseworker.

\footnotetext{
${ }^{3}$ In reality, however, the policy was slightly less strict. In case invitees did not turn up without communicating a legitimate reason, they would receive a reminder by registered post. If they still did not respond, their file would be discarded from the FETOs unemployment registry and transmitted to the NEO, that could then decide on applying benefit sanctions.
} 
The target of the FETO was to invite the middle aged for a collective information session within three months after being enrolled as unemployed. However, the timing of sending out this first invitation did in practice vary a lot across individuals, which created a potential context of implementing an experiment that randomizes and dichotomizes this waiting list. The Flemish Ministry of Labour ruled that such an intervention was compliant with internal ethical procedures as it would not lead to suboptimal use of resources nor to discrimination. Moreover, the results of the experiment could be important in the debate on the reforming of the employment agency, which made that the FETO was keen to facilitate the research project. We hence agreed that the treatment group would be contacted to attend such a collective information session right after the start of their unemployment spell, i.e., within the first four weeks. The control group would only receive an invitation around four to five months after they entered unemployment, with the aim to offer them an information session five months after entering unemployment.

Attending an information session could lead to follow-ups and participants could be encouraged to apply for certain subsidies or to start a training trajectory. It should be noted, however, that the control group basically had the same opportunities for other FETO services during the first months of the unemployment spell than the treatment group. Moreover, they were free to visit a FETO branch to make an appointment and to talk to a caseworker, to call the central service number where specialized agents could give them advice, or to apply online for employment and training subsidies. 


\section{The Implementation of the Randomization and Descriptives}

\subsection{The Sample and the Randomization}

The case study area ${ }^{4}$ is relatively poor, and its unemployment rate is high compared to the level of Flanders, as is shown in Figure 1 for the period January 2010 until June 2015 and for the age range of 25 to 49 . The curve representing the case study area is at all times clearly above the curve depicting the situation at the level of Flanders. Between January 2010 and June 2015, the unemployment rate depicted for the case study area fluctuates between 5.8 and 8.9 , and is between 0.6 and 2.1 percentage points higher than the corresponding region-level unemployment rate.

The sample inflow spans the period from 1 January 2014 until 31 January 2015. After that date, the inflow in the experiment has been ceased since the implementation of new and more centralized procedures (see VDAB, 2015b) compromises comparability with the earlier inflow. ${ }^{5}$

The labelling for the experiment was accomplished by the central IT services based in the FETO headquarters in Brussels. Individuals were assigned to the experiment, on the first day of the unemployment spell when the following conditions were being met:

\footnotetext{
${ }^{4}$ This is the area for which the local FETO office that we collaborate with is responsible.

${ }^{5}$ We are, however, still able to track our sample after the inflow has been ceased.
} 
- They are residing in the area for which the FETO office participating to the case study is responsible.

- They belong to the middle aged group (25-49).

- At the time of enrolment, the central database does not flag that the individual is impeded to participate (e.g. not speaking Dutch, being chronically ill).

- They did not attend any information session during the last two years.

The use of a random generator built into many statistical software packages would be an obvious way to divide the sample into a control and a treatment group. However, the nature of the trial implies that the sample is building up continuously, which complicates this procedure. Since the intervention starts almost right from the start, any delays in assignment should be avoided. Hence, to make the randomization feasible and transparent, we agreed upon a randomization rule that is based on the day-of-month of the individual's date-of-birth. Those who were born on an even day of the month were allocated to the treatment group, while those born on an odd day of the month were allocated to the control group. Since the date-of-birth is a variable included in the dataset, we could easily verify that the labelling was implemented correctly by the IT services. 


\subsection{Descriptives and Compliance}

The total sample contains 1,549 individuals, of which 789 belong to the control group and 760 to the treatment group. The slightly larger size of the control group is in line with the fact that there are more odd than even days in a year. We use anonymized standard data from the FETO, for which the FETO has the permission to use these for research purposes from the Belgian Privacy Commission. This permission is structural and does not need to be obtained for each individual research project, nor is explicit consent required from the individuals to whom these data refer. The downside is, of course, that our admin data include a rather limited list of variables.

Table 1 shows descriptive statistics of both the treatment and control group of baseline values of observable characteristics. The last column shows P-values of tests, that test the null hypothesis of equality between control and treatment group. ${ }^{6}$

A large proportion in our sample has low education $(32.1 \%$ in the treatment group versus $29.8 \%$ in the control group). In both the treatment and control group, just under half the sample is female. Furthermore, $7.6 \%$ and $8.9 \%$ are labelled as foreigners in our sample for the treatment and control group respectively. ${ }^{7}$ Finally, it is interesting

\footnotetext{
${ }^{6}$ We use Pearson $\chi^{2}$-tests for the categorical variables and Mann-Whitney tests for the ordered variables.

${ }^{7}$ One is labelled as foreigner if one of the unemployed worker's current or past nationalities is from outside the European Free Trade Association. We should emphasize that the proportion of foreigners among the unemployed in our case study region is larger than in our sample, since the experiment does not include those for whom it was known a priori that their knowledge of Dutch was insufficient to benefit from the information session.
} 
to note that only less than a third of the unemployed enrolled themselves through the online platform (28.8\% in the treatment group and $30.6 \%$ in the control group).

The last column shows us that only for the age, the null hypothesis of equality between treatment and control group can be rejected at the $5 \%$ significance level. Hence, it seems reasonable to assume that we are dealing with type I error, and we will attempt to mitigate this sampling error by including baseline characteristics as controls in our estimation models. Moreover, since we have access to the exact date-of-birth in our data, we have been able to verify that the IT services have implemented the randomization procedure correctly: those born on an even day of the month were all labelled as treatment group, and those born on an odd day of the month were all labelled as control group.

Finally, an important question remains whether indeed the instructions have been followed by the job coaches and the experiment has been carried out correctly. Although it was not possible to retrieve reliable data on the exact date individuals have received a first invitation for an information session, we do have reliable attendance data, since these are being meticulously registered as they are important for monitoring purposes. The latter data can offer us a second-best compliance check, as they inform us about whether the time elapsed between enrolment is in line with the template of the experiment. As mentioned earlier, due to a variety of reasons many unemployed workers in the treatment group did not attend the information session: only $33 \%$ of the subjects in the treatment group have eventually attended a session. Conditional on having followed 
the information session, the median time elapsed between inflow into the sample and attending a session equals 56 days, and $89 \%$ of the treated individuals who actually attended an information session did so within the 120 days time span after their inflow into the sample.

The timings of the control group's attendance is more informative to judge whether the FETO office managed to comply with the experiments template: we would expect individuals to have participated outside the 120-days time span after inflow into the sample. For individuals in the control group and conditional on having attended an information session, the median time elapsed between the inflow into the sample and attendance equals 192 days. Only two out of the 74 cases have a higher risk to be noncompliant, as they attended an information session 22 and 57 days after inflow, respectively. This means that an invitation might have been sent well before the target of four to five months after enrolment, but it might also indicate that these individuals spontaneously asked to attend a session. The other cases were within the range of 157 and 364 days, which is in accordance with the experiment's template. We need to stress that the descriptives on attendance only serve the purpose of a second-best compliance check. As the control group gets the invitation later in the spell, it is obvious that a smaller percentage than in the treatment group will eventually attend a session since those in the control group had more time to find a job. 


\section{Baseline Empirical Framework and Pathways to Impact}

\subsection{Baseline Empirical Framework}

Throughout our analysis, we will attempt to measure intention-to-treat effects rather than treatment effects of the information session. Firstly, many will never complete the treatment and attend a session as they can delay attendance until having found a job. Secondly, despite filtering at the central level based on available data, after the start of the experiment, it sometimes turned out that ones situation had changed (moving to another region, turning 50) or that the central database was not up to date. We will not exclude these misclassified individuals from the experiment, since misclassifications and other issues will be detected more frequently in the treatment group than in the control group, and hence removing them would distort the random allocation. We should hence interpret the estimation results as a lower bound of the effect that such an early intervention can have on the treated.

All individuals who enter our sample are initially unemployed. As we deal with a randomized experiment, we are able to show clear-cut nonparametric causal evidence by presenting overlay scatter plots of treatment and control group, that depict the percentage of individuals at work in function of the number of days after inflow into the 
sample. Further regression models (with parametric restrictions) will then help us to get some more insights into the statistical significance of these results.

We will estimate the exit rate into part-time or full-time employment. Our data contain many other categories which the unemployed could transit to, e.g. full-time training, work-disabled etc. However, we will only concentrate on finding a job instead of a competing risk model for two sets of reasons. First, there are a few statistical reasons: our sample is too small to divide the data into many different outflow categories, and multiple categories might bias our estimates in case of irrelevant alternatives. Second, there are pragmatic concerns that weigh in. A batch procedure regularly updates the FETO datafiles with information about clients having found a job, through matching the FETO records with a central database of the Belgian social security. The transition to categories other than work would only be registered if they are entered manually (either by the caseworker or the unemployed), and since the treatment group is contacted earlier than the control group, we might risk measuring the correction of administrative files rather than an actual change in the individual's status.

For each individual, the research period is truncated at 120 days after being enrolled as unemployed because after that time the employment service will start inviting the control group for the information session, and other measures such as reduction of unemployment benefits might start influencing the results. ${ }^{8}$ On average, $41 \%$ of all un-

\footnotetext{
${ }^{8}$ The baseline model will investigate whether during these 120 days, there is a transition to work, but will not investigate unemployment recurrence. We will however partly address this concern in one of the extensions.
} 
employed workers have experienced a transition into work within these first 120 days. There obviously is considerable heterogeneity across groups. For example, the average transition rate for those with low education is only $34 \%$, compared to $43 \%$ and $49 \%$ for those with intermediate and high education, respectively.

Exit rates from unemployment to employment are generally very much dependent on calendar time. The economic development as well as seasonal effects ${ }^{9}$ will determine in- and outflow. Moreover, the limited number of observations require us to make a careful trade-off between flexibility and efficiency. Hence, the regression model which seems most appropriate for the baseline analysis and which has been applied often in employment research (e.g. Dohmen and Pfann, 2004) is the Cox proportional hazard model.

With the Cox proportional hazard model, one can estimate the hazard rate $\lambda\left(t, t_{0}, A_{T}, X\right)$, which is the chance that one finds a job on a certain day $t$, conditional on the day $t_{0}$ of becoming unemployed, on a dummy $A_{T}$ indicating whether one is allocated to the treatment group or not, and on a set of covariates $X$. The hazard rate can in turn be written as:

$$
\lambda_{0}\left(t, t_{0}\right) \exp \left(\beta_{0}+\beta_{1} A_{T}+X \beta\right)
$$

Where $\lambda_{0}\left(t, t_{0}\right)$ is a time-dependent baseline hazard, $\beta_{0}$ a constant and $\beta$ a vector of coefficients to be estimated. Hence, the hazard rate is the baseline hazard multiplied

\footnotetext{
${ }^{9}$ As Figure 1 illustrates, since our case study takes place in a coastal area, unemployment peaks in winter time. In the whole of Flanders unemployment peaks after the summer due to the inflow of school leavers into the labour market.
} 
by an exponential factor that depends on the values of $A_{t}$ and $X$. The exponential function is used merely to ensure that the hazard rate will never turn negative. In the regression tables, we will show the exponentiated versions of the estimated coefficients, as they are easy to interpret as a proportional change in the baseline hazard rate. The exponentiated $\beta$-coefficients will always be strictly larger than 0 : if $\beta_{j}>1$, there is a positive association between the exit rate and $x_{j}$ and vice versa.

The main independent variable is $A_{T}$, a dummy which takes one when being allocated to the treatment group, zero otherwise. Since the allocation to the treatment group is exogenous by construction, we do in principle not need to include controls. However, for completeness and to mitigate potential sampling bias, we will also show specifications including baseline covariates discussed in Section 3.2. We are well aware that the impact of the treatment might be heterogeneous across groups. E.g., Altmann et al. (2015) find that providing information has the largest impact for groups that are most at risk to become long-term unemployed. Therefore, we add an analysis which allows the treatment effect to be different for unemployed individuals with low, intermediate-level or high education, three groups across which we see a large heterogeneity in overall exit rates. Hence, the estimated hazard rate will be modified as:

$$
\lambda_{0}\left(t, t_{0}\right) \exp \left(\beta_{0}+\beta_{1} A_{T} * E_{L}+\beta_{2} A_{T} * E_{I L}+\beta_{3} A_{T} * E_{H}+\beta_{4} * E_{L}+\beta_{5} * E_{I L}+X \beta\right)
$$


With $E_{L}, E_{I L}$, and $E_{H}$ dummies for low education, intermediate level education and high education respectively. Also, as an additional check, we will run split-sample regressions according to education instead of using the above model with interaction terms. The reason for this check is twofold. Firstly, such split-sample regressions are not subject to a concern that interaction terms in nonlinear models can lead to considerable biases (Ai and Norton, 2003). Secondly, we can relax the assumption that the baseline hazard function is the same across the education levels.

\subsection{Partial versus General Equilibrium Effects}

We are aware that there might be a difference between a partial equilibrium effect (as measured throughout the analysis) and a general equilibrium effect (Crépon et al., 2013; Gautier et al., 2012): Expanding the treatment to the whole region or country might lead to a zero-effect due to crowding out, even if there is a positive partial equilibrium effect in a pilot study. The presence of such crowding-out might lead us to overestimate the impact of the treatment on the treatment group (or the partial equilibrium effect). Indeed, we are estimating how much the treatment group works more relative to the control group. However, this relative effect can be a mixture of the treatment group working more, and the control group working less. In the worst case scenario, one extra day of work for an individual in the treatment group is one day less for an individual in the control group. Under the latter scenario, the intention-to-treat effect on the number of days worked should be halved to obtain a correct estimate. It seems, however, very 
unlikely that the extreme case holds. The study (control and treatment group) only considers the middle-aged for one local area, so if there is complete crowding out, the price is not likely to be paid entirely by the control group, but also by other age categories as well as by the unemployed in adjacent areas.

\subsection{Pathways to Impact}

Insights from recent behavioural economics teach us that we can change people's perceptions in a relatively inexpensive way.

Firstly, individuals might learn from the information session itself and effective counselling might lead to more successful job search. For example, research by Altmann et al. (2015) shows that merely providing information about job search strategies, the labour market and related issues will have a small positive impact on the job finding rate for certain subgroups.

Secondly, being contacted early in the unemployment spell might lead to an increase in perceived social norms, that is, the expectations of friends and relatives. Since people are likely to be sensitive to social norms on the importance of finding a job when choosing their actions (Ellickson, 1998), higher perceived social norms might encourage individuals to intensively search for jobs right from the start. Similarly, being contacted might lead to higher perceived monitoring. In a context of tax compliance, Fellner et al. (2013) find that rather neutral mailings can have a large impact on people's per- 
ceived chance of being inspected. We can expect that a very early intervention might positively affect the exit rate from unemployment through similar channels as receiving a letter to attend a mandatory information and coaching session conveys a message of strict monitoring. This might be an important channel since, as we saw above, we are measuring an intention-to-treat effect and only a fraction of the treatment group will have attended the session within the 120-days time span under study.

Finally, one might also expect that there are channels through which a negative impact can occur. The unemployed might feel offended to be contacted and hence monitored straight from the start. ${ }^{10}$ Hence, one might decide to punish the employment agency in a way that is not too costly for themselves (Belot and Schröder, forthcoming). The latter channel is not likely to play an important role in this context, since delaying exit from unemployment (compared to the counterfactual) will always bring along substantial costs for the individual such as foregone income.

\section{Results}

\subsection{Descriptive Nonparametric Results}

Let us first turn to the graphs depicted in Figures 2 to 4 . All figures are overlay scatter plots of treatment and control group. The X-axis shows the number of days from enrol-

\footnotetext{
${ }^{10}$ In fact, we received some anecdotal evidence on this from the local FETO office.
} 
ment into unemployment (or, more precisely, from inflow into the sample) ranging from zero to 120. The Y-axis shows the percentage of individuals into employment. Hence, all curves in all three figures will start at the crossing of $\mathrm{X}$ - and $\mathrm{Y}$-axis, since by definition one is unemployed at day Zero.

The two scatter plots in Figure 2 depict the relationship between days-since-inflow and percentage at work for the entire sample. The figure reveals that there is hardly any difference in percentage at work between treatment and control group up to 60 days after inflow. From day 60 onwards the treatment group is slightly more at work than the control group. At day 90 the figure reveals a jump in the difference in percentage at work in favour of the treatment group. This difference remains more or less the same until the end of the experiment at day 120. Figure 3 shows the results for the subsample of the low-educated. The figure clearly reveals the widening of a gap in the percentage at work from day 30 onwards. At that day the percentage at work starts increasing faster for the treatment than for the control group. At the end of the period the difference in percentage at work is about 10 percentage points in favour of the treatment group. Finally, Figure 4 shows us the development of the percentage at work for the group of intermediate- and high-educated. The figure shows that for the unemployed with an intermediate or high educational background no consistent differences over time between treatment and control group can be detected. 


\subsection{Baseline Regression Results}

Table 2 contains the baseline results of our analysis. Column 1 presents a Cox proportional hazard model which only includes a treatment dummy. In column 2, baseline controls have been added to the model. Columns 3 and 4 show models that are identical to the models displayed in Columns 1 and 2, respectively, but allow for a heterogeneous treatment effect across the different education levels.

The baseline specification in column 1 shows a coefficient on the treatment dummy of 1.11, which means that the intention-to-treat leads to a multiplication of the baseline hazard rate by 1.11. Standard errors are, however, large such that the coefficient is not significantly different from one at conventional significance levels $(\mathrm{P}=0.19)$.

We could think of several reasons why the overall effect is not significant. Firstly, the impacts of ALMPs can be heterogeneous, and a treatment can be more useful for one group of individuals than for another. Secondly, the actual point estimate is not that small given the modesty of the intervention. Since the standard errors are large, we might well be facing power issues. Indeed, the relatively small sample size is restrictive, given the fact that we are studying an inexpensive and light intervention (which means that we want to be able to detect even small effects), and given that we are measuring an intention-to-treat effect rather than a treatment effect of participating in a mandatory information session in itself. 
Column 2 shows that including the available baseline controls hardly alters the coefficient on the treatment dummy. The coefficients on the controls reveal however some interesting patterns. The exit rate for those with low education is clearly lower than the exit rate for those with high education (with a coefficient of 0.66 ), and also being a foreigner is associated with almost a halving of the exit rate (coefficient of 0.56). However, the estimation results do not show any significant differences by gender and age, nor for those who enrolled through the Internet in the unemployment registration.

Columns 3 and 4 show that there are heterogeneous treatment effects across levels of education. Both models offer us almost identical results. Looking at column 4, it turns out that, although being low-educated is associated with a much lower exit rate compared to being high-educated (coefficient of 0.54 ), the interaction term between loweducated and the treatment dummy is large with a magnitude of 1.50 and a P-value of 0.01 . This means that low-educated unemployed workers who are allocated to the treatment group have a Hazard rate which is 1.50 times higher than the exit rate of low-educated individuals in the control group. For these low-educated individuals, the impact of being allocated to the treatment group appears to be substantial, even if one only wishes to accept the lower bound of 1.09 of the $95 \%$ confidence interval as the actual impact of the intention-to-treat. ${ }^{11}$

\footnotetext{
${ }^{11}$ The investigation of heterogeneous effects might come with worries of data mining. However, we believe that our choice for education has a strong conceptual basis since the exit rate from unemployment to employment varies a lot by the level of education. One might obviously let the data speak, and run a large set of models with different interaction effects. Unfortunately, we do not have much reliable administrative data for such an exercise, but there does not seem to be an interaction effect with gender. There seems to be an interaction effect with being foreign but being foreign is highly correlated with being low-educated.
} 
Results of split-sample regressions, with the sample split according to the level of education, are presented in Table 3. It is reassuring to see that the split-sample regression results show very similar results for the low-educated as the regressions with interaction terms in Table 2.

As mentioned in Section 3.1, we chose the day-of-month of one's date-of-birth to divide the sample into a treatment and control group rather than a random generator, and this was for practical reasons. However foreigners who come from less developed countries often do not have an official birth certificate, and their registered date-of-birth might then be a guestimate. This guestimate is then often the first day of the month or year, which would jeopardize the compliance of our experiment. Indeed, from the 128 foreigners in our data, four of them are born on January 1, which is an unusual high number. In total, 12 of them are born on the first day of the month. Hence, Table 4 shows results of similar specifications as displayed in column 3 and column 4 of Table 2 again, but now after excluding the 12 non-natives who were born on the first day of the month. We see that the interaction term of being treated and having low education decreases somewhat, but still remains significant with a P-value of 0.02 .

Although we seem to be able to identify a positive causal intention-to-treat effect for the low-educated, the analysis remains rather reduced-form as it is hard to disentangle the different channels through which this effect occurs. Obviously, the information given throughout the information session can be very useful to optimize search strategies and to get prepared for the job market. However, there are some indications to make us believe 
that the monitoring and social norms channels could play an important role as well, and that not just the information session itself, but also merely being contacted to attend a mandatory information session, can invoke behaviour changes. Firstly, as we saw in Section 3.2, only around $33 \%$ of the individuals in the treatment group actually attended a session. Secondly, we have explored whether attending a session was a predictor of transition from unemployment to employment. It turns out, however, that those who actually attend a session stay in unemployment significantly longer than people in the control group, and others in the treatment group who did not participate into the session. Keeping in mind the positive intention-to-treat effect on employment chances, the latter clearly indicates a selection effect: those who actually participate in the information session are those with the lowest chance to find a job, and the latter results could indicate that the positive intention-to-treat effect is driven not just by the information session itself, but by being contacted to attend the information session. This reasoning is obviously speculative: since this concerns a comparison of session attendants of the treatment group with the entire control group, we cannot exclude that the treatment effect is caused by the fact that hard-to-place individuals attending a session in the treatment group find a job more quickly than their counterparts in the control group.

\subsection{Cost-Benefit Analysis}

The baseline models give us an idea of the shift in exit rates between the treatment and control group. For a cost-benefit analysis of this labour market policy instrument, it is 
desirable to estimate the actual difference for treatment and control groups in number of days worked during the 120-days time span after a workers inflow into unemployment. The latter would also be a response to the concern that our Cox proportional hazard models do not take into account unemployment recurrence. Therefore, in Table 5, we show similar analyses as in column 3 and column 4 of Table 2, but now analyzing the data using a Zero-inflated Poisson count model.

The dependent variable is now the number of days one has been in regular part-time or full-time work during the 120 days after entering the sample, which equals to zero for around $59 \%$ of the sample. ${ }^{12}$ The Zero-Inflated Poisson Model consists of two equations. First, there is a Logit equation which estimates the odds of having worked zero days, and next a Poisson equation which estimates the workdays conditional on having worked a strictly positive number of days. The results of each of both models are presented across three columns. A first column shows us the marginal effect on workdays conditional on having worked a strictly positive number of days, a second column the change in log of odds of having worked zero days, and a final column offers us the overall marginal effect on the number of workdays.

Both models again show us a significant impact on the low-educated subsample. According to the full model, being treated and low-educated changes the log odds of having worked Zero days by -0.5. Interestingly, conditional on having worked a positive number of days, being allocated to the treatment group reduces the number of days

\footnotetext{
${ }^{12}$ As for interim work we cannot measure the exact number of days that these occasional jobs have taken. Therefore we cannot take account of these employment spells in our analyses.
} 
worked by 0.06 days. The overall marginal effect, however, is positive and amounts to 6.5 (P-value of 0.04). After converting this latter number to a five-day working week by multiplying by $5 / 7$, we find that allocation to the treatment group leads to an increase of 4.7 working days for those with low education in the 120-days time span after becoming unemployed. Table 6 contains results from models similar to those displayed in Table 5, but now OLS regressions have been used rather than Zero-inflated Poisson models: the former regressions are easier to read than the latter, and although they are less suitable given the distribution of the dependent variable, we do not need to be concerned about the biases that can arise when including interaction terms in nonlinear models. Even though the standard errors in Table 6 seem to be somewhat larger than in Table 5 , it is reassuring to see that results are very similar.

An approximate cost-benefit analysis shows promising results for the endorsement of the cost-effectiveness of this early intervention. The FETO has advised us that the total cost of one information session can be estimated at EUR 785. ${ }^{13}$ Since generally 30 individuals are invited for each information session, this boils down to around EUR 26 per head. ${ }^{14}$ Concerning the benefits, the NEO advised us that on average, the daily benefit payment to a low-educated unemployed individual amounts to EUR 38. This means that the procedure is already cost-effective if it would return one additional day

\footnotetext{
${ }^{13}$ EUR 750 is staff cost, half a day administration plus two times half a day for the two caseworkers being present at the session. The cost of a room is EUR 35 for half a day.

${ }^{14}$ We decided to divide the costs by the number of invitees rather than by a guestimate of the number of individuals turning up, since we are measuring intention-to-treat effects and since these costs are not dependent on the number of people actually showing up.
} 
of employment within these 120 days. Our estimate of 4.7 days is hence clearly above this threshold.

We need, however, to make three additional remarks. Firstly, one might argue that we are underestimating the costs of the treatment, since after the information session there might be follow-ups and people could decide to start a costly training programme. Even though we cannot entirely exclude the possibility of an underestimation of these costs, we have good reasons to believe that these will be minor. The FETO indeed runs an extensive set of courses, varying from short online modules to more intensive training. However, within the 120-days window which we are investigating, only $6 \%$ in the treatment group participated in a training programme, compared to $4 \%$ of the control group. Secondly, one might worry that crowding out does play a role, and that the 4.7 days are hence an overestimate of the intention-to-treat effect. As discussed in Section 4.2 , under the very unlikely worst-case scenario, we would need to correct this regression estimate by halving it. This would leave us with a return of 2.35 days, which would still mean that the treatment is cost-effective. Thirdly, there is a chance that the post-unemployment job quality is different between the treatment and control group. Unfortunately, we do not have access to wage or other related data. At the start of our project, we have investigated the possibilities of merging the administrative data from the FETO with other wage- and employment-related data, which are coordinated by the Belgian Social Security. However, such a merge would not comply with the strict rules of the Belgian Privacy Commission, as it would increase the chance to be able to identify 
the individuals in the dataset, and to extract sensitive personal information. We hence need to stress that the cost-benefit analysis needs to be interpreted with a margin, and seen as a first rough estimate.

\subsection{Increasing the Time Span}

Finally, one might like to obtain an idea of the longer-term impact on employment of being allocated to the treatment group. Therefore, Table 7 repeats the estimations displayed in Table 5, but now extending the time period to 150 and 180 days after entering unemployment. Hence, we now allow our research period to overlap with the time period in which individuals allocated to the control group are being contacted as well.

The overall marginal effect of being allocated to the treatment group and having low education increases to 9.0 when we extend our research period to a 150 -days time span, and to 10.8 when we extend the time span to 180 days (P-values of 0.03 ). After converting the results to a five-day working week, we obtain that being allocated to the treatment group increases the number of days worked by 6.4 in a 150-days time span and 7.7 in a 180-days time span.

Table 9 further investigates whether the difference in employment status between treatment and control group persists or rather diminishes over time. The table shows the marginal effects of Probit models with the same independent variables as in Table 
7. The dependent variables of the specifications are dummies which take the value one if the individual is in work on day 120, 150, or 180 respectively. For those with low education, column 1 of Table 9 shows that for the unemployed in the treatment group, the probability of being in work on day 120 is almost 11 percentage points higher than for those in the control group $(\mathrm{P}$-value $=0.02)$. For the days 150 and 180, this effect decreases to around 6 percentage points, and the estimates are not significant any more at conventional significance levels. This slight convergence over time after the period of the field experiment is probably at least partly due to the fact that after four months, individuals in the control group are also being invited for the information session and become hence subject to the same procedures as those in the treatment group. ${ }^{15}$

\section{Conclusion}

Unemployment has been an all-time important social issue, and is especially salient in the era of the post-2008 financial crises. While it is well-known that unemployment is as a drama at the individual level and is a burden to a society's economy, there is still a lot to learn about which kind of ALMPs are effective in which context. Although governments are well-aware of the importance to tackle unemployment, austerity measures have often led to directing resources to the long-term unemployed, and to economize on the coaching of those who freshly entered an unemployment spell. There might however be good

\footnotetext{
${ }^{15}$ For completeness, models in Table 7 and Table 9 have been replicated with OLS regressions in Table 8 and 10 respectively, and again results seem to be confirmed with these alternative specifications.
} 
reasons to believe that early interventions are most effective as they could prevent longterm unemployment. If workers are unemployed for a longer time they might find it much harder to get back on track because of the well-documented scarring effects reducing mental and physical health (see, for example, Knabe and rätzel, 2011) and because of the negative signal a long unemployment spell sends to potential employers (Kroft et al., 2013). Fortunately, we have learnt from recent behavioural economics that even cheap interventions can induce behaviour changes (see, for example, Altmann and Traxler, 2014; Fellner et al., 2013) and hence in this paper, we evaluate whether contacting the unemployed right from the start to attend a mandatory information session has a positive impact on the transition from unemployment into work. While those allocated to the treatment group were contacted within the first four weeks of the unemployment spell, those allocated to the control group were contacted around four to five months after entering unemployment with as an aim to offer them a session five months after registration.

We find that contacting the unemployed at the start of the cycle has a positive impact on the probability to find a job: especially those with low education will benefit, and will have worked 4.7 days more than their counterparts in the control group during the first four months after entering unemployment.

Even though the randomization of the timing of contacting the unemployed facilitates the measurement of a causal intention-to-treat effect on the exit rate from unemployment to employment, the analysis is reduced-form when it comes to disentangling the different 
channels through which such an effect can occur. There are several possibilities, and an obvious one is that individuals receive very relevant information during the information session that can help them to look for a job more efficiently and to better prepare themselves for the labour market. However, we also argued that at least a significant part of the effect might well be due to merely having received a formal invitation to attend a mandatory information session, rather than due to the information session itself.

Obviously our results should not be used to argue that the intervention should only be applied to those with low education. Since the intervention is very cheap, it would be cost-effective even if on average, it would lead to less than one additional day of employment. Our sample however $(\mathrm{n}=1,549)$ does not offer us sufficient statistical power to measure such small effects with statistical significance. Moreover, in other institutional contexts, the size and the distribution of the impact of similar early interventions might be different from the one we studied.

The main message that can be taken from our study is that relatively cheap early interventions (with a mandatory component) targeting freshly-unemployed individuals can have a significant positive impact on the transition into work, making these interventions highly cost-effective. Our paper hence contributes to the recent behavioural economics literature that has shown that light and inexpensive interventions can induce relatively large behaviour changes. Moreover, it contributes to the on-going policy debate on how to allocate resources to ALMPs by showing that a minimum of personal coaching instead 
of digital self-service facilities for those who have just become unemployed is likely to be very cost-effective.

\section{References}

Ai, C. and E. Norton (2003) Interaction Terms in Logit and Probit Models. Economics Letters 80, 123-129.

Altmann, S., A. Falk, S. Jäger \& F. Zimmermann (2015) Learning about Job Search: A Field Experiment with Job Seekers in Germany. IZA Discussion Papers, 9040.

Altmann, S. \& C. Traxler (2014) Nudges at the Dentist. European Economic Review $72,19-38$.

Belot, M. \& M. Schröder (Forthcoming) The Spillover Effects of Monitoring: A Field Experiment. Management Science.

Blundell, R., M. Costa Dias, C. Meghir \& J. Van Reenen (2004) Evaluating the Employment Impact of a Mandatory Job Search Programme. Journal of the European Economic Association 2, 569-606.

Card, D., J. Kluve \& A. Weber (2010) Active Labour Market Policy Evaluations: A Meta-Analysis. Economic Journal 120, F452-F477. 
Crépon, B., E. Duflo, M. Gurgand, R. Rathelot \& P. Zamora (2013) Do Labor Market Policies Have Displacement Effects? Evidence from a Clustered Randomized Experiment. Quarterly Journal of Economics 128, 531-580.

Crossley, T., J. de Bresser, L. Delaney \& J. Winter (2014) Can Survey Participation Alter Household Saving Behaviour? IFS Working Paper, 14/06, Forthcoming in the Economic Journal.

Dohmen, T. \& G. Pfann (2004) Worker Separations in a Nonstationary Corporate Environment. European Economic Review 48, 645-663.

Ellickson, R. (1998) Law and Economics Discovers Social Norms. Journal of Legal Studies 27, 537-552.

Fellner, G., R. Sausgruber \& C. Traxler (2013) Testing Enforcement Strategies in the Field: Threat, Moral Appeal and Social Information. Journal of the European Economic Association 11, 634-660.

Gautier, P., P. Muller, B. van der Klaauw, M. Rosholm \& M. Svarer (2012) Estimating Equilibrium Effects of Job Search Assistance. Economics Working Papers 2012-27, School of Economics and Management, University of Aarhus.

Graversen, B. \& J. van Ours (2011) An Activation Program as a Stick to Job Finding. Labour 25, 167-181. 
Hijzen, A., R. Upward \& P. Wright (2010) The Income Losses of Displaced Workers. Journal of Human Resources 45, 679-686.

Knabe, A. \& S. Rätzel (2011) Scarring or Scaring? The Psychological Impact of Past Unemployment and Future Unemployment Risk. Economica 78, 283-293.

Kroft, K., F. Lange \& M. Notowidigdo (2013) Duration Dependence and Labor Market Conditions: Evidence from a Field Experiment. Quarterly Journal of Economics $128,1123-1167$.

Oreopoulos, P., T. von Wachter \& A. Heisz (2012) The Short- and Long-Term Career Effects of Graduating in a Recession. American Economic Journal: Applied Economics 4, 1-29.

Van der Klaauw, B. \& J. Van Ours (2013) Carrot and Stick: How Re-Employment Bonuses And Benefit Sanctions Affect Exit Rates From Welfare. Journal of Applied Econometrics 28, 275-296.

Van Ours, J. (2004) The locking-in Effect of Subsidized Jobs. Journal of Comparative Economics 32, 37-55.

VDAB (2014) Jaarverslag 2013. Vlaamse Dienst voor Arbeidsbemiddeling en Beroepsopleiding, Brussels.

VDAB (2015a) Jaarverslag 2014. Vlaamse Dienst voor Arbeidsbemiddeling en Beroepsopleiding, Brussels. 
VDAB (2015b) Sluitend Maatpak Realiseren. Vlaamse Dienst voor Arbeidsbemiddeling en Beroepsopleiding, Internal Powerpoint Presentation, Brussels. 
Table 1: Baseline Characteristics for Treatment and Control Group: A Randomization Check

\begin{tabular}{|c|c|c|c|}
\hline Categoric & \multicolumn{3}{|c|}{ Categorical Variables } \\
\hline$\%$ female & 47.4 & 49.3 & 0.45 \\
\hline$\%$ foreigner & 7.6 & 8.9 & 0.37 \\
\hline$\%$ enrolment through Internet & 28.7 & 30.5 & 0.39 \\
\hline \multicolumn{4}{|c|}{ Ordered Variables } \\
\hline average age & 35.7 & 36.5 & 0.05 \\
\hline quarter of inflow & & & 0.16 \\
\hline$\%$ inflow Quarter 1 & 26.7 & 24.8 & \\
\hline$\%$ inflow Quarter 2 & 19.3 & 18.2 & \\
\hline$\%$ inflow Quarter 3 & 24.5 & 24.1 & \\
\hline education & & & 0.84 \\
\hline$\%$ low education & 32.1 & 29.8 & \\
\hline$\%$ intermediate education & 49.1 & 53.4 & \\
\hline
\end{tabular}

P-values are derived from Pearson $\chi^{2}$-tests for the categorical variables and MannWhitney tests for the ordered variables. The null hypothesis = equality between the samples of control and treatment group. 
Table 2: Estimation of Transition to Work Using Cox Proportional Hazard Models: Baseline Results

\begin{tabular}{|c|c|c|c|c|}
\hline & spec 1 & spec 2 & spec 3 & spec 4 \\
\hline treatment & $\begin{array}{l}1.109 \\
(0.088)\end{array}$ & $\begin{array}{c}1.099 \\
(0.087)\end{array}$ & & \\
\hline treatment $*$ low educ & & & $\begin{array}{c}1.511 \\
(0.242)^{* * *}\end{array}$ & $\begin{array}{c}1.497 \\
(0.240)^{* *}\end{array}$ \\
\hline treatment $*$ intermediate educ & & & $\begin{array}{c}0.994 \\
(0.107)\end{array}$ & $\begin{array}{c}0.979 \\
(0.106)\end{array}$ \\
\hline treatment $*$ high educ & & & $\begin{array}{l}1.007 \\
(0.173)\end{array}$ & $\begin{array}{l}1.024 \\
(0.176)\end{array}$ \\
\hline low education & & $\begin{array}{c}0.666 \\
(0.079)^{* * *}\end{array}$ & $\begin{array}{c}0.513 \\
(0.090)^{* * *}\end{array}$ & $\begin{array}{c}0.541 \\
(0.096)^{* * *}\end{array}$ \\
\hline intermediate education & & $\begin{array}{c}0.871 \\
(0.089)\end{array}$ & $\begin{array}{c}0.872 \\
(0.126)\end{array}$ & $\begin{array}{c}0.888 \\
(0.130)\end{array}$ \\
\hline female & & $\begin{array}{l}0.897 \\
(0.071)\end{array}$ & & $\begin{array}{c}0.901 \\
(0.072)\end{array}$ \\
\hline age & & $\begin{array}{l}0.998 \\
(0.005)\end{array}$ & & $\begin{array}{c}0.997 \\
(0.005)\end{array}$ \\
\hline enrolment through Internet & & $\begin{array}{l}1.104 \\
(0.096)\end{array}$ & & $\begin{array}{l}1.108 \\
(0.097)\end{array}$ \\
\hline foreigner & & $\begin{array}{c}0.562 \\
(0.101)^{* * *}\end{array}$ & & $\begin{array}{c}0.562 \\
(0.101)^{* * *}\end{array}$ \\
\hline$N$ & 1,549 & 1,549 & 1,549 & 1,549 \\
\hline
\end{tabular}


Table 3: Estimation of Transition to Work Using Cox Proportional Hazard Models: Split Sample Results

\begin{tabular}{|c|c|c|c|c|}
\hline & \multicolumn{2}{|c|}{ Sample Low Educated } & \multicolumn{2}{|c|}{ Remaining Sample } \\
\hline & spec 1 & spec 2 & spec 3 & spec 4 \\
\hline \multirow[t]{2}{*}{ treatment } & 1.500 & 1.488 & 1.003 & 0.991 \\
\hline & $(0.240)^{* *}$ & $(0.239)^{* *}$ & $(0.092)$ & $(0.091)$ \\
\hline \multirow[t]{2}{*}{ female } & & 0.946 & & 0.895 \\
\hline & & $(0.150)$ & & $(0.082)$ \\
\hline \multirow[t]{2}{*}{ age } & & 1.015 & & 0.991 \\
\hline & & $(0.011)$ & & $(0.006)$ \\
\hline \multirow[t]{2}{*}{ enrolment through Internet } & & 0.978 & & 1.152 \\
\hline & & $(0.196)$ & & $(0.112)$ \\
\hline \multirow[t]{2}{*}{ foreigner } & & 0.498 & & 0.607 \\
\hline & & $(0.156)^{* *}$ & & $(0.133)^{* *}$ \\
\hline$N$ & 479 & 479 & 1,070 & 1,070 \\
\hline
\end{tabular}


Table 4: Estimation of Transition to Work Using Cox Proportional Hazard Models: Removing Foreigners Born on First Day of Month

\begin{tabular}{|c|c|c|}
\hline & spec 1 & spec 2 \\
\hline treatment & $\begin{array}{l}1.091 \\
(0.086)\end{array}$ & \\
\hline low education & $\begin{array}{c}0.670 \\
(0.080)^{* * *}\end{array}$ & $\begin{array}{c}0.550 \\
(0.097)^{* * *}\end{array}$ \\
\hline intermediate education & $\begin{array}{c}0.869 \\
(0.089)\end{array}$ & $\begin{array}{c}0.883 \\
(0.129)\end{array}$ \\
\hline female & $\begin{array}{c}0.890 \\
(0.071)\end{array}$ & $\begin{array}{l}0.895 \\
(0.071)\end{array}$ \\
\hline age & $\begin{array}{c}0.998 \\
(0.005)\end{array}$ & $\begin{array}{l}0.997 \\
(0.005)\end{array}$ \\
\hline enrolment through Internet & $\begin{array}{l}1.103 \\
(0.096)\end{array}$ & $\begin{array}{l}1.107 \\
(0.097)\end{array}$ \\
\hline foreigner & $\begin{array}{c}0.600 \\
(0.110)^{* * *}\end{array}$ & $\begin{array}{c}0.597 \\
(0.109)^{* * *}\end{array}$ \\
\hline treatment $*$ low educ & & $\begin{array}{c}1.463 \\
(0.234)^{* *}\end{array}$ \\
\hline treatment $*$ intermediate educ & & $\begin{array}{c}0.979 \\
(0.106)\end{array}$ \\
\hline treatment $*$ high educ & & $\begin{array}{l}1.017 \\
(0.175)\end{array}$ \\
\hline$N$ & 1,537 & 1,537 \\
\hline \multicolumn{3}{|c|}{$* p<0.1 ; * * p<0.05 ; * * * p<0.01$} \\
\hline $\begin{array}{l}\text { Standard Errors in P } \\
\text { Coefficients Are Exp }\end{array}$ & $\begin{array}{l}\text { rentheses } \\
\text { nentiated }\end{array}$ & \\
\hline
\end{tabular}


Table 5: Estimation of Days Worked within 120 Days after Inflow Using Zero-Inflated Poisson Models

\begin{tabular}{|c|c|c|c|c|c|c|}
\hline & Poisson & Logit & Overall marginal & Poisson & Logit & Overall marginal \\
\hline treatment $*$ low educ & $\begin{array}{c}-0.067 \\
(0.019)^{* * *}\end{array}$ & $\begin{array}{c}-0.529 \\
(0.196)^{* * *}\end{array}$ & $\begin{array}{c}6.657 \\
(3.183)^{* *}\end{array}$ & $\begin{array}{c}-0.063 \\
(0.020)^{* * *}\end{array}$ & $\begin{array}{c}-0.517 \\
(0.199)^{* * *}\end{array}$ & $\begin{array}{c}6.510 \\
(3.186)^{* *}\end{array}$ \\
\hline treatment $*$ intermediate educ & $\begin{array}{l}-0.011 \\
(0.013)\end{array}$ & $\begin{array}{r}-0.007 \\
(0.144)\end{array}$ & $\begin{array}{l}-0.182 \\
(2.329)\end{array}$ & $\begin{array}{r}-0.014 \\
(0.013)\end{array}$ & $\begin{array}{c}0.023 \\
(0.146)\end{array}$ & $\begin{array}{l}-0.739 \\
(2.336)\end{array}$ \\
\hline treatment $*$ high educ & $\begin{array}{l}-0.041 \\
(0.022)^{*}\end{array}$ & $\begin{array}{c}-0.033 \\
(0.241)\end{array}$ & $\begin{array}{l}-0.591 \\
(3.908)\end{array}$ & $\begin{array}{c}-0.063 \\
(0.022)^{* * *}\end{array}$ & $\begin{array}{l}-0.045 \\
(0.245)\end{array}$ & $\begin{array}{l}-0.976 \\
(3.917)\end{array}$ \\
\hline low education & $\begin{array}{c}0.115 \\
(0.022)^{* * *}\end{array}$ & $\begin{array}{c}0.886 \\
(0.227)^{* * *}\end{array}$ & $\begin{array}{c}-11.080 \\
(3.676)^{* * *}\end{array}$ & $\begin{array}{c}0.103 \\
(0.022)^{* * *}\end{array}$ & $\begin{array}{c}0.822 \\
(0.234)^{* * *}\end{array}$ & $\begin{array}{c}-10.250 \\
(3.747)^{* * *}\end{array}$ \\
\hline intermediate education & $\begin{array}{c}0.062 \\
(0.018)^{* * *}\end{array}$ & $\begin{array}{c}0.207 \\
(0.200)\end{array}$ & $\begin{array}{l}-1.635 \\
(3.234)\end{array}$ & $\begin{array}{c}0.048 \\
(0.019)^{* *}\end{array}$ & $\begin{array}{c}0.207 \\
(0.205)\end{array}$ & $\begin{array}{r}-1.989 \\
(3.284)\end{array}$ \\
\hline female & & & & $\begin{array}{c}0.022 \\
(0.010)^{* *}\end{array}$ & $\begin{array}{c}0.166 \\
(0.106)\end{array}$ & $\begin{array}{l}-2.045 \\
(1.698)\end{array}$ \\
\hline age & & & & $\begin{array}{c}0.000 \\
(0.001)\end{array}$ & $\begin{array}{l}0.002 \\
(0.007)\end{array}$ & $\begin{array}{r}-0.023 \\
(0.116)\end{array}$ \\
\hline enrolment through Internet & & & & $\begin{array}{l}0.009 \\
(0.011)\end{array}$ & $\begin{array}{l}-0.159 \\
(0.121)\end{array}$ & $\begin{array}{c}2.768 \\
(1.930)\end{array}$ \\
\hline foreigner & & & & $\begin{array}{c}-0.109 \\
(0.024)^{* * *}\end{array}$ & $\begin{array}{c}0.668 \\
(0.214)^{* * *}\end{array}$ & $\begin{array}{c}-13.477 \\
(3.434)^{* * *}\end{array}$ \\
\hline$N$ & & & 1,549 & & & 1,549 \\
\hline
\end{tabular}

${ }^{*} p<0.1 ;{ }^{* *} p<0.05 ;{ }^{* * *} p<0.01$

Standard Errors in Parentheses

The second model includes month-of-inflow dummies. 
Table 6: Robustness Check: Estimation of Days Worked within 120 Days after Inflow Using OLS

\begin{tabular}{|c|c|c|}
\hline & Spec. 1 & Spec. 2 \\
\hline treatment $*$ low educ & $\begin{array}{c}6.463 \\
(3.527)^{*}\end{array}$ & $\begin{array}{c}5.944 \\
(3.520)^{*}\end{array}$ \\
\hline treatment $*$ intermediate educ & $\begin{array}{l}-0.197 \\
(2.744)\end{array}$ & $\begin{array}{l}-0.442 \\
(2.742)\end{array}$ \\
\hline treatment $*$ high educ & $\begin{array}{l}-0.729 \\
(4.649)\end{array}$ & $\begin{array}{l}-1.235 \\
(4.634)\end{array}$ \\
\hline low education & $\begin{array}{l}-10.770 \\
(4.188)^{* *}\end{array}$ & $\begin{array}{c}-9.635 \\
(4.256)^{* *}\end{array}$ \\
\hline intermediate education & $\begin{array}{l}-1.499 \\
(3.839)\end{array}$ & $\begin{array}{l}-1.951 \\
(3.875)\end{array}$ \\
\hline female & & $\begin{array}{l}-2.137 \\
(1.962)\end{array}$ \\
\hline age & & $\begin{array}{l}-0.012 \\
(0.134)\end{array}$ \\
\hline enrolment through Internet & & $\begin{array}{l}2.698 \\
(2.249)\end{array}$ \\
\hline foreigner & & $\begin{array}{c}-11.588 \\
(3.589)^{* * *}\end{array}$ \\
\hline Constant & $\begin{array}{c}30.323 \\
(3.346)^{* * *}\end{array}$ & \\
\hline$R^{2}$ & 0.01 & 0.03 \\
\hline$N$ & 1,549 & 1,549 \\
\hline
\end{tabular}


Table 7: Estimation of Days Worked within 150 and 180 Days after Inflow Using ZeroInflated Poisson Models

\begin{tabular}{lcccccc} 
& \multicolumn{3}{c}{ 150-days time span } & \multicolumn{3}{c}{ 180-days time span } \\
\hline & Poisson & Logit & Overall marginal & Poisson & Logit & Overall marginal \\
\hline treatment * low educ & 0.052 & -0.334 & 9.011 & 0.080 & -0.256 & 10.823 \\
& $(0.016)^{* * *}$ & $(0.192)^{*}$ & $(4.080)^{* *}$ & $(0.014)^{* * *}$ & $(0.190)$ & $(5.036)^{* *}$ \\
treatment * intermediate educ & -0.009 & 0.052 & -1.426 & -0.060 & -0.073 & -1.162 \\
& $(0.011)$ & $(0.145)$ & $(3.068)$ & $(0.010)^{* * *}$ & $(0.144)$ & $(3.829)$ \\
treatment * high educ & -0.024 & 0.019 & -1.312 & -0.053 & -0.033 & -1.869 \\
& $(0.018)$ & $(0.245)$ & $(5.193)$ & $(0.016)^{* * *}$ & $(0.246)$ & $(6.507)$ \\
low education & -0.018 & 0.734 & -16.128 & -0.047 & 0.723 & -21.414 \\
& $(0.019)$ & $(0.229)^{* * *}$ & $(4.862)^{* * *}$ & $(0.016)^{* * *}$ & $(0.228)^{* * *}$ & $(6.041)^{* * *}$ \\
intermediate education & 0.006 & 0.191 & -3.763 & -0.009 & 0.190 & -5.461 \\
female & $(0.015)$ & $(0.205)$ & $(4.342)$ & $(0.013)$ & $(0.205)$ & $(5.429)$ \\
age & -0.006 & 0.123 & -2.830 & -0.014 & 0.105 & -3.498 \\
enrolment through Internet & $(0.008)$ & $(0.105)$ & $(2.219)$ & $(0.007)^{* *}$ & $(0.104)$ & $(2.762)$ \\
& 0.000 & 0.002 & -0.030 & 0.001 & 0.006 & -0.098 \\
foreigner & $(0.001)$ & $(0.007)$ & $(0.152)$ & $(0.000)^{* *}$ & $(0.007)$ & $(0.189)$ \\
$N$ & 0.020 & -0.146 & 3.834 & 0.065 & -0.012 & 3.645 \\
& $(0.009)^{* *}$ & $(0.119)$ & $(2.531)$ & $(0.008)^{* * *}$ & $(0.119)$ & $(3.161)$ \\
& -0.120 & 0.660 & -18.465 & -0.112 & 0.658 & -23.029 \\
& $(0.019)^{* * *}$ & $(0.205)^{* * *}$ & $(4.364)^{* * *}$ & $(0.017)^{* * *}$ & $(0.200)^{* * *}$ & $(5.320)^{* * *}$ \\
& & & 1,549 & & & 1,549 \\
\hline
\end{tabular}

${ }^{*} p<0.1 ;{ }^{* *} p<0.05 ;{ }^{* * *} p<0.01$

Standard Errors in Parentheses

All models include month-of-inflow dummies. 
Table 8: Robustness Check: Estimation of Days Worked within 150 and 180 Days after Inflow Using OLS

\begin{tabular}{lcc}
\hline & 150-days time span & 180-days time span \\
\hline treatment ${ }^{*}$ low educ & 8.068 & 9.513 \\
treatment ${ }^{*}$ intermediate educ & $(4.606)^{*}$ & $(5.712)^{*}$ \\
treatment ${ }^{*}$ high educ & -0.925 & -0.855 \\
low education & $(3.588)$ & $(4.448)$ \\
& -1.576 & -2.177 \\
intermediate education & $(6.063)$ & $(7.518)$ \\
& -15.293 & -20.608 \\
female & $(5.569)^{* * *}$ & $(6.906)^{* * *}$ \\
& -4.006 & -6.009 \\
age & $(5.070)$ & $(6.287)$ \\
& -2.988 & -3.548 \\
enrolment through Internet & $(2.568)$ & $(3.184)$ \\
& -0.036 & -0.088 \\
foreigner & $(0.175)$ & $(0.218)$ \\
$R^{2}$ & 3.667 & 3.873 \\
$N$ & $(2.942)$ & $(3.649)$ \\
\hline
\end{tabular}

${ }^{*} p<0.1 ;{ }^{* *} p<0.05 ;{ }^{* * *} p<0.01$ 
Table 9: Marginal Effects of Probit Estimations on Working at Day 120, 150 and 180 Respectively after Inflow in Sample

\begin{tabular}{|c|c|c|c|}
\hline & at day 120 & at day 150 & at day 180 \\
\hline treatment $*$ low educ & $\begin{array}{c}0.283 \\
(0.123)^{* *}\end{array}$ & $\begin{array}{c}0.164 \\
(0.119)\end{array}$ & $\begin{array}{l}0.147 \\
(0.119)\end{array}$ \\
\hline treatment $*$ intermediate educ & $\begin{array}{c}0.003 \\
(0.091)\end{array}$ & $\begin{array}{l}-0.036 \\
(0.091)\end{array}$ & $\begin{array}{l}0.027 \\
(0.090)\end{array}$ \\
\hline treatment $*$ high educ & $\begin{array}{c}0.032 \\
(0.153)\end{array}$ & $\begin{array}{l}-0.053 \\
(0.153)\end{array}$ & $\begin{array}{c}0.023 \\
(0.152)\end{array}$ \\
\hline low education & $\begin{array}{c}-0.534 \\
(0.145)^{* * *}\end{array}$ & $\begin{array}{c}-0.465 \\
(0.142)^{* * *}\end{array}$ & $\begin{array}{c}-0.420 \\
(0.142)^{* * *}\end{array}$ \\
\hline intermediate education & $\begin{array}{l}-0.152 \\
(0.128)\end{array}$ & $\begin{array}{r}-0.160 \\
(0.128)\end{array}$ & $\begin{array}{l}-0.128 \\
(0.128)\end{array}$ \\
\hline female & $\begin{array}{r}-0.086 \\
(0.066)\end{array}$ & $\begin{array}{l}-0.050 \\
(0.065)\end{array}$ & $\begin{array}{l}-0.059 \\
(0.065)\end{array}$ \\
\hline age & $\begin{array}{l}-0.002 \\
(0.005)\end{array}$ & $\begin{array}{l}-0.004 \\
(0.004)\end{array}$ & $\begin{array}{l}-0.006 \\
(0.004)\end{array}$ \\
\hline enrolment through Internet & $\begin{array}{l}0.101 \\
(0.075)\end{array}$ & $\begin{array}{l}0.037 \\
(0.075)\end{array}$ & $\begin{array}{l}-0.007 \\
(0.075)\end{array}$ \\
\hline foreigner & $\begin{array}{c}-0.413 \\
(0.130)^{* * *}\end{array}$ & $\begin{array}{c}-0.387 \\
(0.125)^{* * *}\end{array}$ & $\begin{array}{c}-0.389 \\
(0.125)^{* * *}\end{array}$ \\
\hline$N$ & 1,549 & 1,549 & 1,549 \\
\hline
\end{tabular}

Standard Errors in Parentheses

All models include month-of-inflow dummies. 
Table 10: Robustness Check: LPM Estimates of Working at Day 120, 150 and 180 Respectively after Inflow in Sample

\begin{tabular}{|c|c|c|c|}
\hline & at day 120 & at day 150 & at day 180 \\
\hline treatment $*$ low educ & $\begin{array}{c}0.094 \\
(0.044)^{* *}\end{array}$ & $\begin{array}{l}0.058 \\
(0.045)\end{array}$ & $\begin{array}{l}0.052 \\
(0.045)\end{array}$ \\
\hline treatment $*$ intermediate educ & $\begin{array}{c}0.002 \\
(0.034)\end{array}$ & $\begin{array}{l}-0.014 \\
(0.035)\end{array}$ & $\begin{array}{l}0.011 \\
(0.035)\end{array}$ \\
\hline treatment $*$ high educ & $\begin{array}{l}0.012 \\
(0.058)\end{array}$ & $\begin{array}{l}-0.021 \\
(0.059)\end{array}$ & $\begin{array}{l}0.009 \\
(0.059)\end{array}$ \\
\hline low education & $\begin{array}{c}-0.191 \\
(0.053)^{* * *}\end{array}$ & $\begin{array}{c}-0.176 \\
(0.054)^{* * *}\end{array}$ & $\begin{array}{c}-0.159 \\
(0.055)^{* * *}\end{array}$ \\
\hline intermediate education & $\begin{array}{l}-0.059 \\
(0.049)\end{array}$ & $\begin{array}{l}-0.063 \\
(0.050)\end{array}$ & $\begin{array}{l}-0.050 \\
(0.050)\end{array}$ \\
\hline female & $\begin{array}{l}-0.032 \\
(0.025)\end{array}$ & $\begin{array}{l}-0.019 \\
(0.025)\end{array}$ & $\begin{array}{l}-0.023 \\
(0.025)\end{array}$ \\
\hline age & $\begin{array}{l}-0.001 \\
(0.002)\end{array}$ & $\begin{array}{l}-0.001 \\
(0.002)\end{array}$ & $\begin{array}{l}-0.002 \\
(0.002)\end{array}$ \\
\hline enrolment through Internet & $\begin{array}{c}0.036 \\
(0.028)\end{array}$ & $\begin{array}{l}0.012 \\
(0.029)\end{array}$ & $\begin{array}{l}-0.005 \\
(0.029)\end{array}$ \\
\hline foreigner & $\begin{array}{c}-0.137 \\
(0.045)^{* * *}\end{array}$ & $\begin{array}{c}-0.139 \\
(0.046)^{* * *}\end{array}$ & $\begin{array}{c}-0.140 \\
(0.046)^{* * *}\end{array}$ \\
\hline $\begin{array}{l}R^{2} \\
N\end{array}$ & $\begin{array}{c}0.04 \\
1,549\end{array}$ & $\begin{array}{c}0.03 \\
1,549\end{array}$ & $\begin{array}{c}0.03 \\
1,549\end{array}$ \\
\hline
\end{tabular}


Figure 1: The Course of Unemployment over Time at the State Level and the Case Study Region: Ages 25-49

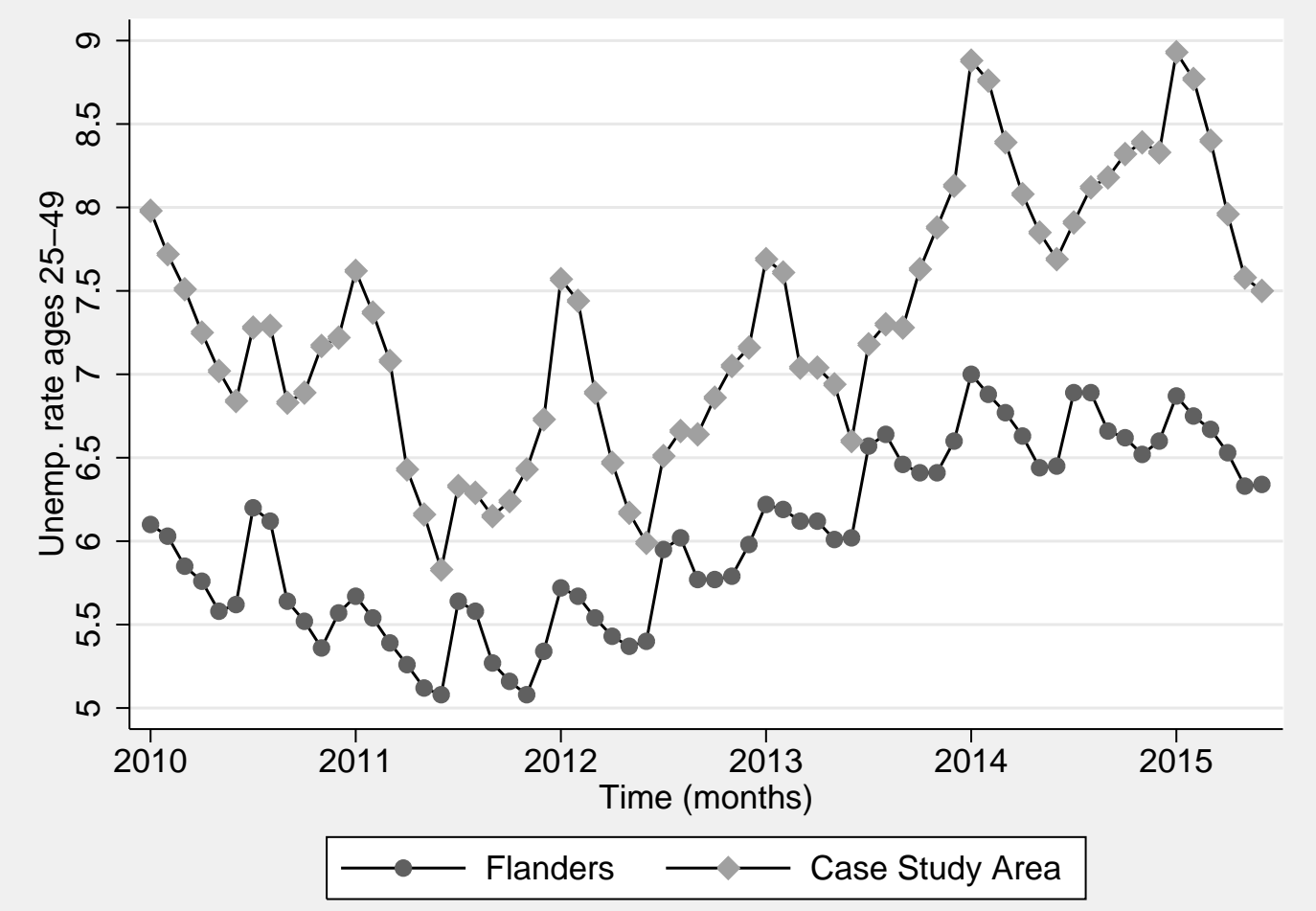


Figure 2: The Percentage of Individuals in Work in Function of the Number of Days since Enrolment at the Employment Office: Full Sample

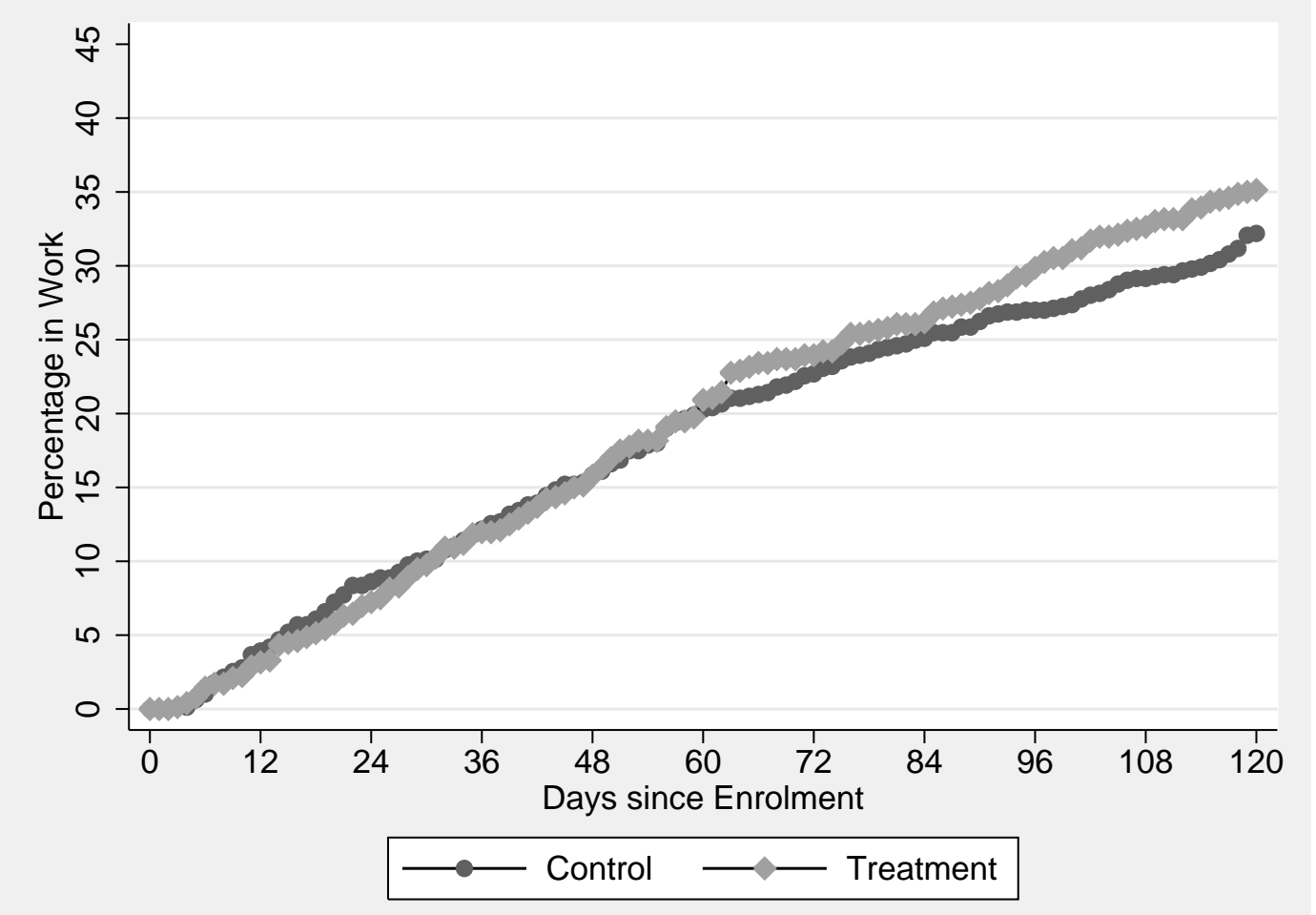


Figure 3: The Percentage of Individuals in Work in Function of the Number of Days since Enrolment at the Employment Office: Sample of Low-Educated

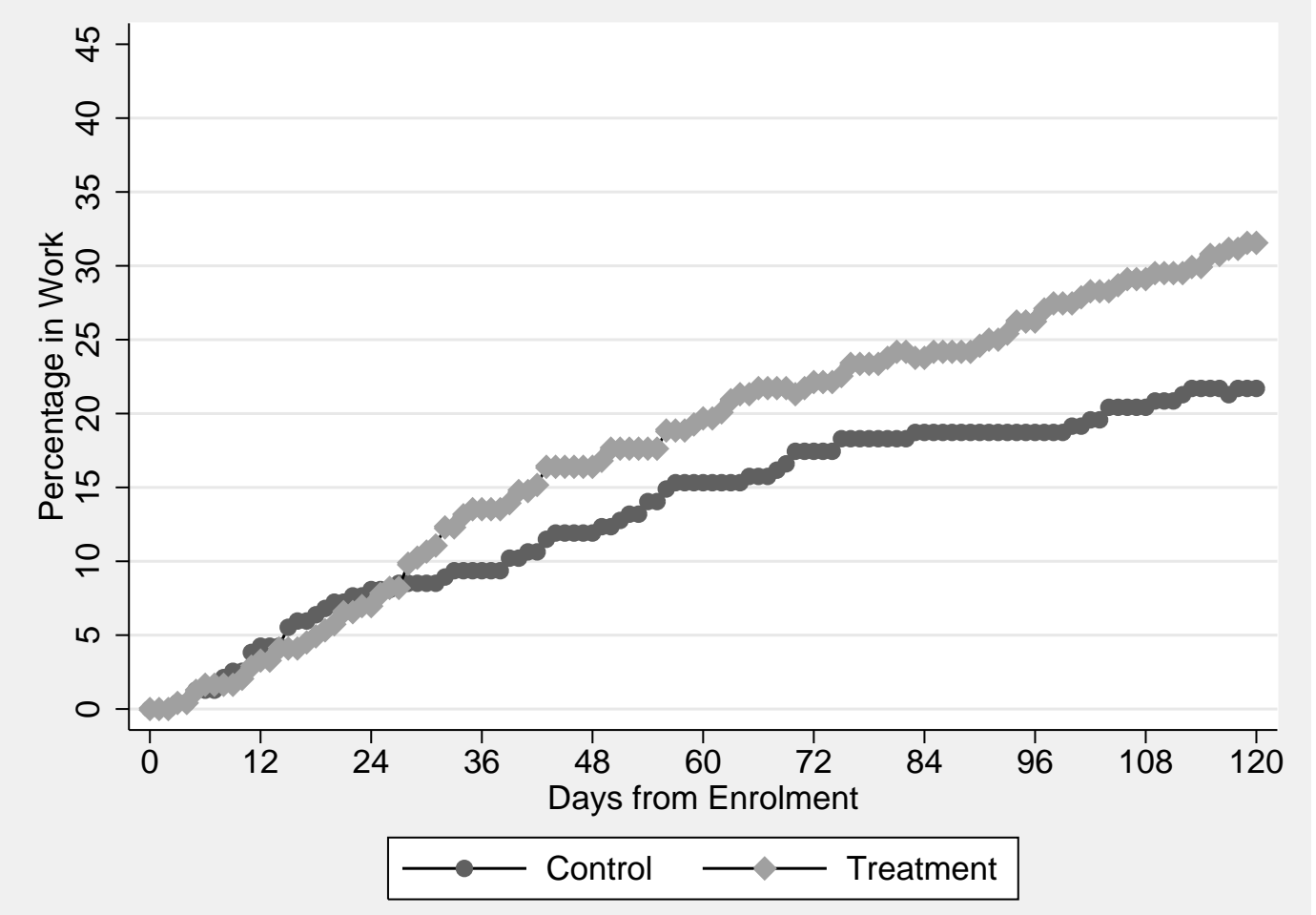


Figure 4: The Percentage of Individuals in Work in Function of the Number of Days since Enrolment at the Employment Office: Sample of the Intermediate- and High-Educated

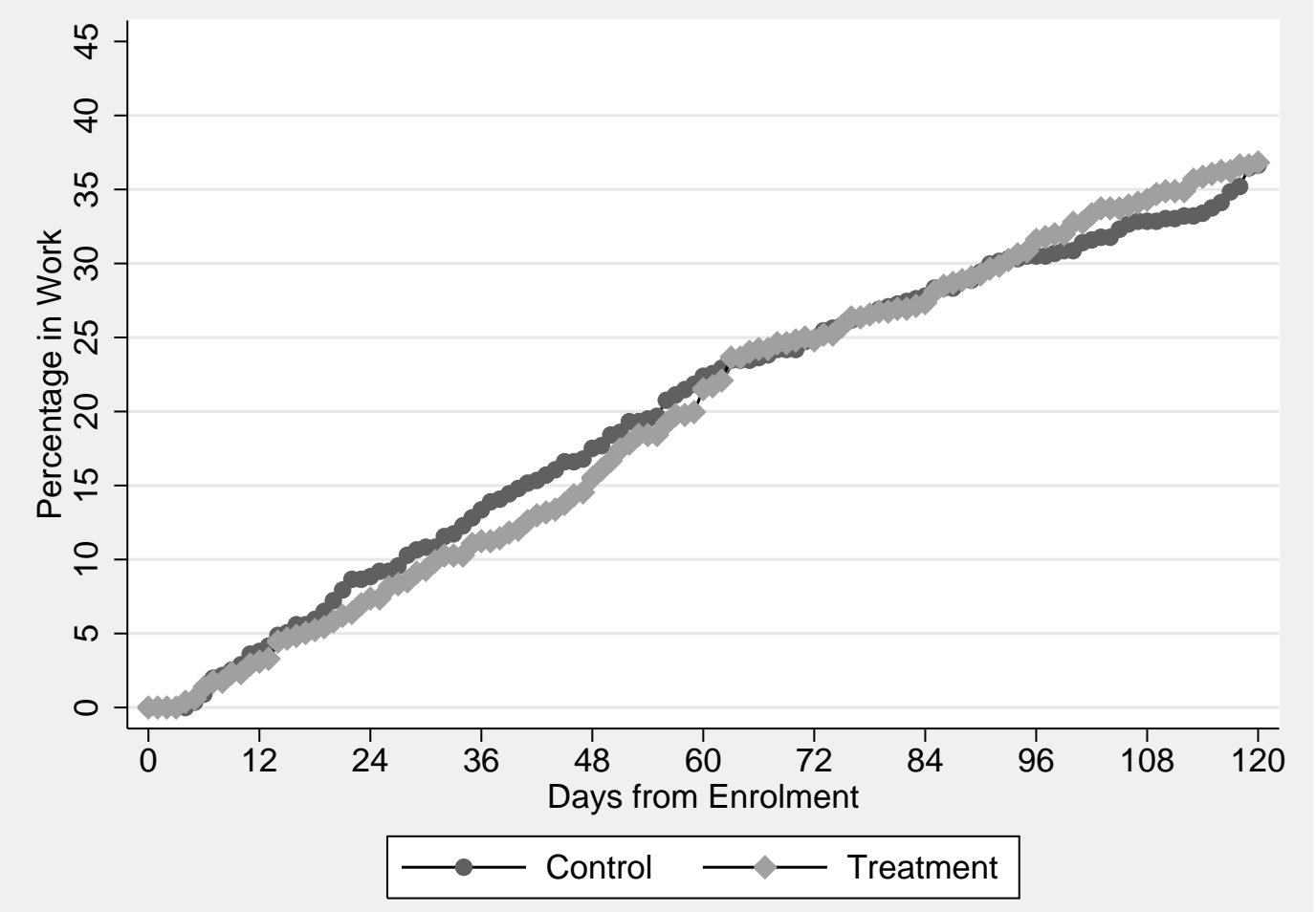

